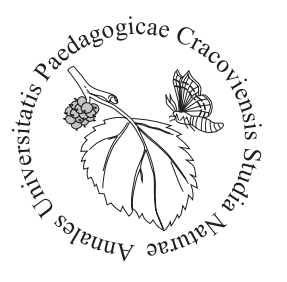

Ksenia Strzeżoń Institute of Biology, Pedagogical University of Krakow, Podchorążych 2 St., 30-084 Kraków, Poland; ksenia1922@gmail.com

\title{
Evaluation of the grassland sward floristic composition of the Wadowice commune
}

\section{Introduction}

Pastures and meadows are mainly anthropogenic (semi-natural) communities, which were created thanks to man. Their existence is conditioned by appropriate management methods, such as mowing, grazing or fertilisation (Kornaś, 1990; Kornaś, Dubiel, 1991; Barabasz, 1994, 2011). Deforested areas, which were not suitable for arable fields due to steep location, high humidity or shallow and relatively infertile soil, were selected for pastures. Meadows were established in places that were relatively easily accessible, although not too distant from the settlement, so that they could be mowed, dried, and conveniently brought hay, which in winter was the only source of feed for farm animals (Kocan, Jacniacki, 1980; Falkowski, 1983).

Proper care of meadows and pastures is necessary because it prevents, for example, the occurrence of undesirable species (Włodarczyk, 1983). High concentrations of organic compounds have a negative effect on many meadow perennials, even those relatively resistant to large amounts of nitrogen, e.g. species from the Fabaceae Lindl. family. These species are eagerly eaten by cattle because they have high nutritional value. Too much manure provides an opportunity for the expansion of nitrophilous species not belonging to the fodder plants, which also adversely affects the usage value of a sward (Kornaś, Dubiel, 1991; Bobbink et al., 1998; Radkowski, Barabasz-Krasny, 2008). Additionally, the lack of light and oxygen can cause damage and rot in many fodder plants. In general, weed infestation of meadow sward reduces its productivity. The most common causes of this phenomenon are improper usage, excess humidity or soil drought, or incorrect nutrient proportions in soil (Haghighi et al., 2010; Teague et al., 2011).

Care treatments and a rationally used mowing and grazing system contribute to improving the floristic composition of green utility areas (Włodarczyk, 1983; Bara- 
basz, 1994; Bakker, Berendse, 1999; Díaz et al., 2007). Moderate grazing has a positive effect on the quality of meadows and pastures because weeds omitted by cattle become visible, and they can easily be mechanically removed (Grynia, 1974). Additionally, soil kneading by animals helps to get rid of weed roots that are not resistant to pressure. Nibbling by animals deprives plants of the aerial parts responsible for photosynthesis, which weakens the growth of many non-resistant weeds (Nowiński, 1970; Pauler et al., 2019). Mowing can contribute to the growth of tall grasses and reduce the number of perennials. During the flowering phase and inflorescence emergence, or earing, tall grasses drown out lower growing weeds and less efficient low grasses. It is best to utilize mowing throughout the season on a separate part of the meadow, collecting up to three swaths (Falkowski, 1983). However, it should be remembered that intensive use of meadows can lead to species poorness (Kornaś, 1990; Sienkiewicz, 2010).

The aim of this study was to (1) analyse the floristic composition, (2) the characteristics and (3) the agricultural suitability of meadows and pastures of the Wadowice commune. To date, no analyses related to this topic have been carried out in this area even though agriculture in the commune of Wadowice is of great importance.

\section{Characteristic of the study area}

The urban and rural commune of Wadowice, together with the city of Wadowice $\left(49^{\circ} 52^{\prime} 57^{\prime \prime} \mathrm{N} 19^{\circ} 29^{\prime} 40^{\prime \prime} \mathrm{E}\right)$, is located in southern Poland in the Lesser Poland Voivodeship. The area of the community is $113 \mathrm{~km}^{2}$, of which $102 \mathrm{~km}^{2}$ is rural and the remainder is city - Wadowice (Local Development Strategy..., 2014). Kondracki (2011) classified the analysed area as extending to the Carpathian and Subcarpathian Provinces, the macroregions of the Western Beskids and the West Beskidian Foothills, as well as to the mesoregions of the Little Beskids and the Wieliczka Foothills. The commune consists of the following land usage elements: agricultural lands (include arable areas, grasslands, orchards) and fallows, forest land, urbanised areas, as well as places under water (Fig. 1).

The Little Beskids can be described as a plateau approximately $35 \mathrm{~km}$ long and $12 \mathrm{~km}$ wide, with an average height of $800 \mathrm{~m}$ a.s.l. From the west, it is limited by the Wilkowicka Gate. The northern border with the Silesian Beskids is demarcated by the Bielsko-Biała-Wadowice road, while the southern and eastern extremities are river valleys, including Łękawka, Kocońka, Tarnawka, Krzeszowski Potok, and Skawa. The Wieliczka Foothills, which are also associated with the study area, cover an area extending east of the Skawa River to the regions of Wieliczka and Gdów. The western part of the Wieliczka Foothills is important for the Wadowice region. Altitudes are approximately $200-550 \mathrm{~m}$ a.s.l. The peaks do not have an island character and are connected with each other by short ridges, forming latitudinal bands (Siemionow, 1984). 


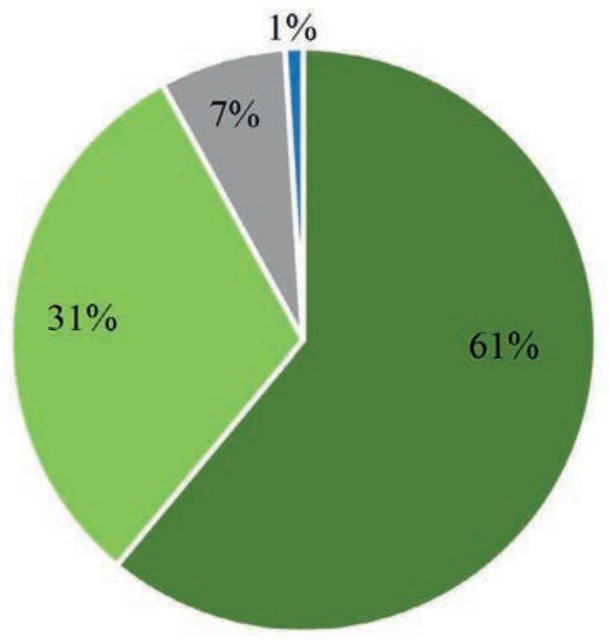

n agricultural lands and fallows

= forest areas

- urbanised places

- areas under water

Fig. 1. The structure of land use in the Wadowice commune (Source: Local Development Strategy..., 2014)

Soils found in the area of the Wadowice commune are mainly shallow, acidic and stony. Most are pseudo-podzols and brown soils. Skeletal and stony soils are also present. Erosion in this area occurs faster than in the lowlands, due to the greater slope and significant rainfall. Many river valleys, as well as the sources and streams present here, favour the development of fertile valley soils. There are fertile soils in the Skawa valley, and the rest of the commune is covered by podzol and brown soils, as well as rusty soils and aerosols (Bednarek, Skiba, 2015).

The area of the Wadowice commune, located in the Little Beskids zone, has a moderate-cold, warm and slightly cold climate (Hess, 1965); respectively, the first is characterised by temperatures from $4^{\circ} \mathrm{C}$ to $6^{\circ} \mathrm{C}$ and the second from $6^{\circ} \mathrm{C}$ to $8^{\circ} \mathrm{C}$. Only in the highest parts can you find the features of a cold climate, with temperatures up to $2^{\circ} \mathrm{C}$. Part of the Wieliczka Foothills has a milder climate, which is illustrated by a higher average temperature of up to $9^{\circ} \mathrm{C}$. An important climatic aspect of the area is the phenomenon of levelling summer-winter differences; the summers are relatively cold and the winters mild, with little snow cover (Woś, 1999).

\section{Material and methods}

The study was conducted in June 2016 in the area of the Wadowice commune. A total of 51 plots with an area of $5 \mathrm{~m} \times 5 \mathrm{~m}\left(25 \mathrm{~m}^{2}\right.$ each $)$ were designated on the meadows and pastures in all municipalities' villages (Fig. 2). A botanical evaluation of meadow sward was performed on each plot using the Klapp (1962) estimation method. Using this method, the share of species in the square was estimated, with an accuracy of $1 \%$, 


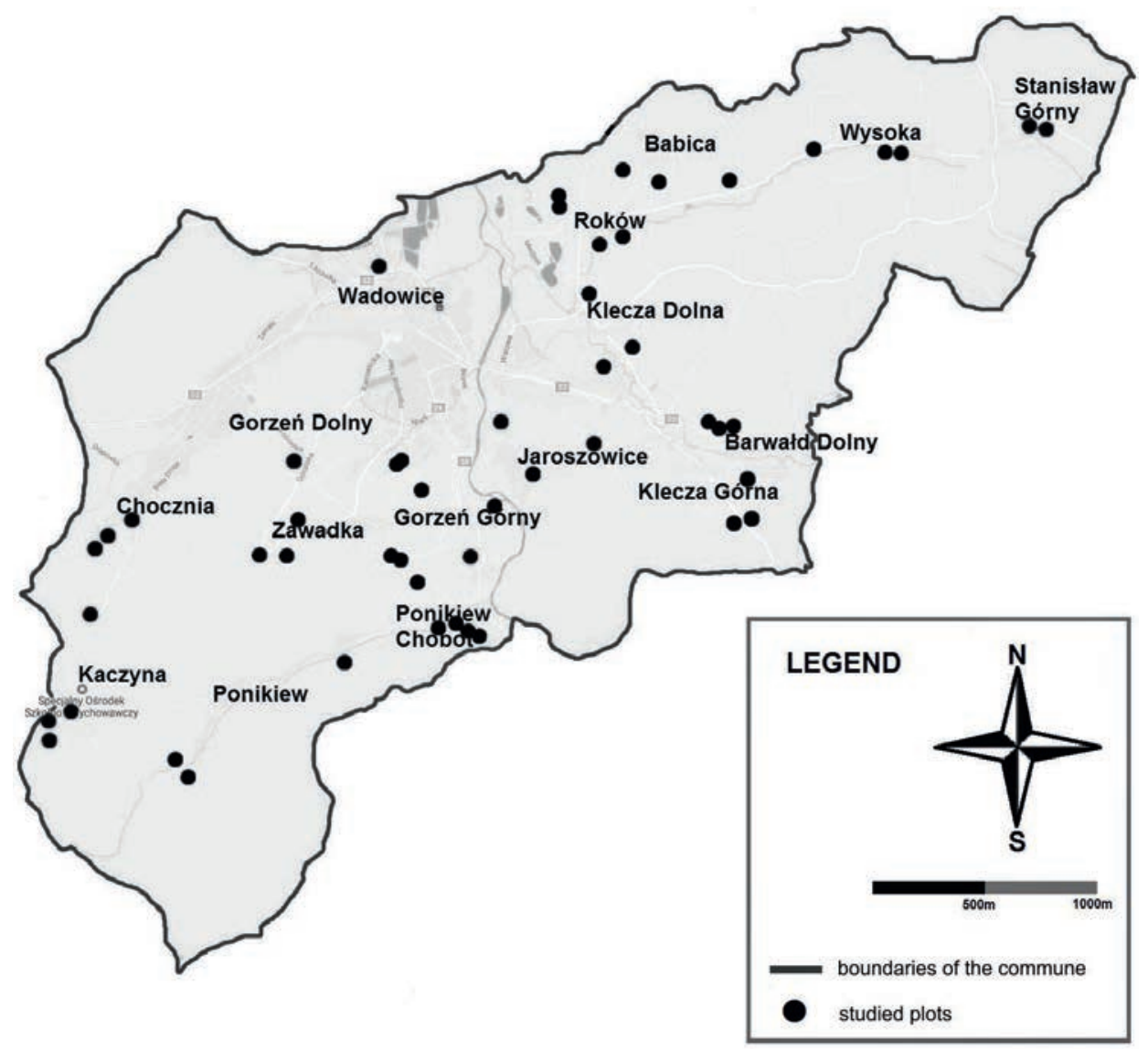

Fig. 2. Distribution of studied plots (1-51) in the Wadowice commune area

recording all species in the order of grasses, legumes, and others. Then the percentage share of individual species within each group was estimated, starting from the most abundant. Species with an occurrence of less than 1\% received the designation "+". Plants that were not directly identified in an area were collected and then identified in laboratory conditions. Szafer et al. (1986) and Nawara (2012) were used as resources to recognise plants. The nomenclature of vascular plants and ferns used in the study was in line with Mirek et al. (2002).

Analyses were carried out using the TURBOVEG program, which is a standard botanical database in Europe. It allows, among other things, for the collection and processing of information about the composition and the share of species in plots (Zarzycki, 2009). Floristic lists of all plots were entered into the database and subjected to numerical classification based on the percent coverage of species. For classification, similarities between plots were calculated using the van der Maarel coefficient (Westhoff, van der Maarel, 1978), according to the formula: 


$$
r(x, y)=\frac{\sum x y}{\sum x^{2}+\sum y^{2}+\sum x y}
$$

where $r$ is the similarity between the plots and $\mathrm{x}, \mathrm{y}$ are vectors of the species percentage occurrence in the plots.

For grouping, the Ward method (Minimum Variance Clustering) was used a value of 0.5 was assumed as a "+" (Dzwonko, 2007). For classification, the MULVA-5 program was used (Wildi, Orlóci, 1996). Based on the resulting dendrogram, tables were constructed that were used for detailed analysis of the botanical composition of similar groups of plots. To characterise the habitat of similar plots, indicator numbers were used (Ellenberg et al., 1992), which is the recommended method of indirect inference (Roo-Zielińska, 2014). Weighted average Ellenberg's indicators values were calculated, in relation to the percentage share of plants for: light (L), humidity $(\mathrm{F})$, soil reaction $(\mathrm{R})$, and nitrogen content in soil $(\mathrm{N})$. Then arithmetic means were calculated for groups of similar plots.

In order to determine the utility values of the studied area, the Usage Value of the Meadow (UVM) was calculated for all plots, and then individual plots were assigned to the utility scale according to Filipek (1973). The calculations were made on the basis of the Use Value Index (UVI), which is assigned to each species fulfilling a utility role, especially forage plants. The UVM index was calculated as the sum of the products of the percentage share of each species and its UVI divided by 100 (Łyszczarz, 2014).

\section{Results}

In the dendrogram of similarity (Fig. 3) two main groups were separated, with one including three smaller subgroups of plots. In total, four groups of similar plots were distinguished, which were marked with numbers I-IV. These groups were named depending on the species that gave the plot appearance: I - plots with Phleum pratense and Vicia cracca, II - plots with Dactylis glomerata and Trifolium repens, III - plots with Holcus lanatus, and IV - plots with Arrhenatherum elatius (Appendix 1 - Tab. $1-4)$.

Comparing the average values of Ellenberg's indicators calculated for groups of similar plots, it was found that group I is characterised by the highest humidity $(\mathrm{F})$ and nitrogen content $(\mathrm{N})$ among all analysed groups, while in group IV indicators for light (L) and soil pH (R) showed the highest values. All of the analysed groups were in the same range of the Ellenberg's indicators values: moderately sunny places, with fresh soils and moderately moist, with a fairly high nitrogen content and a $\mathrm{pH}$ corresponding to slightly acidic soil (Appendix 1 - Tab. 5). 


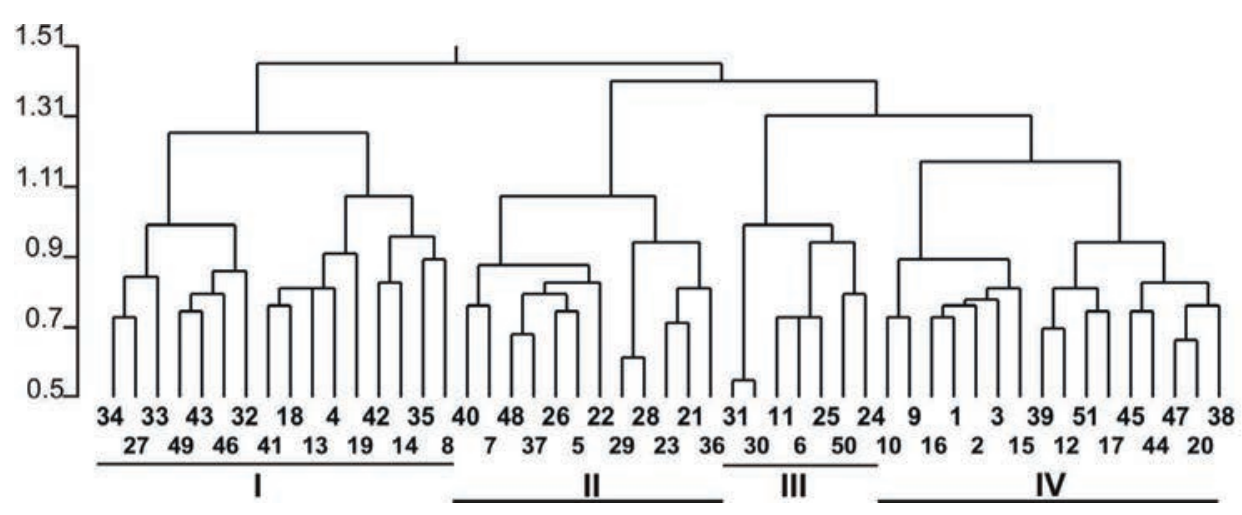

Fig. 3. Classification of the studied plots based on the percentage scale of species coverage: I - plots with Phleum pratense and Vicia cracca, II - plots with Dactylis glomerata and Trifolium repens, III - plots with Holcus lanatus, IV - plots with Arrhenatherum elatius

The studies of the botanical composition of the plots, in terms of use, revealed that most had a good and average UVM. From group IV, only one plot showed very good usage value, and from group I only one plot had poor usage value (Appendix 1 - Tab. 6). Most plots of good usage quality were found in group IV, and the fewest were found in group III. Overall, more than $50 \%$ of the plots had good usage value, and about $40 \%$ were characterised by the average value of the analysed indicator (Fig. 4).

\section{Characteristic of distinguished groups of plots}

\section{Group I - plots with Phleum pratense and Vicia cracca}

(Appendix 1 - Tab. 1)

16 plots were included in the group. Among the grasses, Phleum pratense had the largest share in the plots - from 1 to $40 \%$ coverage per 12 occurrences. Other species, such as Poa pratensis, Anthoxanthum odoratum, Arrhenatherum elatius, Dactylis glomerata, and Alopecurus pratensis, had coverage of up to $60 \%$ in plots, but showed lower numbers of occurrences - from 5 to 9 . Among legumes Vicia cracca was found most often in the plots but with a relatively low coverage - from 1 to $30 \%$. Less often but with larger coverage, Trifolium pratense and T. repens occurred here - from 5 to $50 \%$ coverage per 4-8 occurrences. Among other species, the highest number of occurrences was recorded for Taraxacum officinale - 8, with coverage up to $10 \%$. Certain crops' weeds occur in some plots (e.g. Papaver rhoeas - approx. 1\%) with some having high coverage, e.g. Matricaria maritima ssp. inodora (up to 45\%). The average UVM of these plots was a medium level (Appendix 1 - Tab. 6; Fig. 4). 


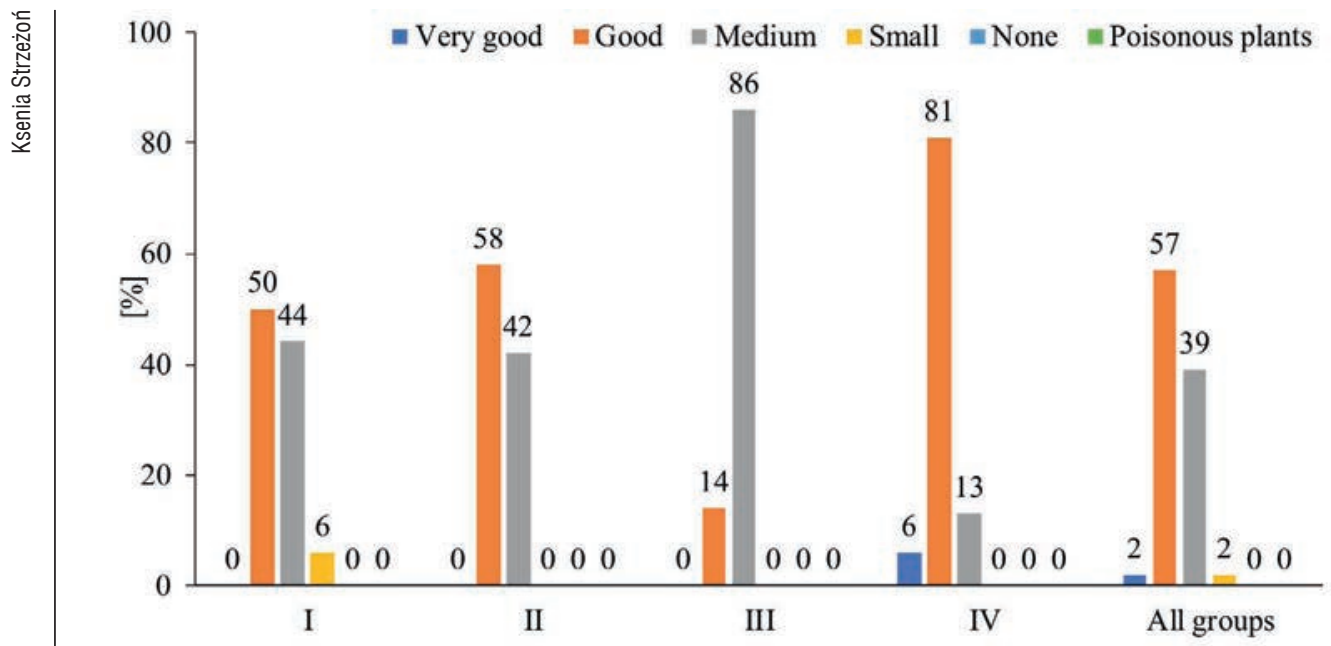

Fig. 4. Comparison of the percentage participation of plots from six usage categories (according to Filipek, 1973) between the groups of meadow distinguished on the study area: I - plots with Phleum pratense and Vicia cracca, II - plots with Dactylis glomerata and Trifolium repens, III - plots with Holcus lanatus, IV - plots with Arrhenatherum elatius

\section{Group II - plots with Dactylis glomerata and Trifolium pratense} (Appendix 1 - Tab. 2)

12 plots were in the group. Of the grasses, the most occurrences were of Dactylis glomerata - 12, reaching 10 to $40 \%$ coverage in plots. The second most common grass was Poa pratensis, which was recorded in 10 plots at 5 to $60 \%$ coverage. Among the legume plants, Trifolium repens deserves attention, which grew on all studied plots with a coverage of 2 to $30 \%$. T. pratense (7 plots) with up to $15 \%$ coverage was also common. Legume species, such as Vicia cracca, Medicago lupulina, and Lathyrus pratensis, which occurred in 2 to 5 plots with a coverage of up to $5 \%$, had a smaller share. Of the other plants growing on the group II plots, the following grazing species were notable: Ranunculus acris, Taraxacum officinale, Plantago lanceolata, and Alchemilla monticola, occurring from + to $10-15 \%$ in plots. Plantago major, typical for trampled sites, was also present in 4 plots - with coverage up to $10 \%$. In terms of average UVM, these plots also were classified at a medium level (Appendix 1 - Tab. 6; Fig. 4).

\section{Group III - plots with Holcus lanatus}

(Appendix 1 - Tab. 3)

7 plots were included in this group. Holcus lanatus exhibited the largest share in this group, growing in all 7 plots, with coverage from 10 to $35 \%$. The second most common grass, present in 6 plots, was Poa pratensis, with coverage from 2 to 35\%. Of the legumes, the following species were notable: Trifolium repens, T. pratense, and Lathyrus pratensis, which, although not present in all plots (from 3 to 5), their coverage was 
relatively large - up to $30 \%$. Among other species, Taraxacum officinale had the largest share (in 5 plots, with coverage up to 20\%) and Plantago major, P. lanceolata, and Leontodon hispidus all reached a maximum of $10 \%$ coverage in plots. They are grazing species, resistant to biting and trampling. In some plots, weeds from arable fields were recorded: Chamomilla recutita and Matricaria maritima ssp. inodora (in 3 and 2 plots, respectively), with coverage of $1 \%$. As in previous groups, the average UVM of these plots was a medium level (Appendix 1 - Tab. 6; Fig. 4).

\section{Group IV - plots with Arrhenatherum elatius}

(Appendix 1 - Tab. 4)

There were 16 plots in this group. Grasses were the most common in this group: Arrhenatherum elatius, Phleum pratense, Dactylis glomerata, and Poa pratensis. A. elatius was recorded in all 16 plots, with coverage of 10 to $50 \%$, with the other grasses noted above being found in 13,12 , and 10 plots, respectively, with coverage of up to $60 \%(D$. glomerata). Of the legume plants, Vicia cracca (11 plots) and Trifolium repens (7 plots) had the largest share. Their coverage was up to a maximum of $10-30 \%$ but usually 1-10\%. Of the other plants, Achillea millefolium was recorded the most (in 15 plots, with coverage 2 to 15\%). Other noticed plants included Ranunculus acris, Taraxacum officinale, Stellaria graminea and Plantago major, associated with pastures. Although buttercup was present in 12 plots, its coverage was small - from $>1$ to $2 \%$. The average UVM of this group of plots was at the level of good (Appendix 1 - Tab. 6; Fig. 4).

Discussion

In meadows and pastures you find not only species that have a positive effect on the quality of fodder but also those that can reduce the utility value and above all threaten the health and life of animals, as they are often poisonous. They can also be harmful to the vegetation of meadows and pastures and hinder hay harvesting or animal grazing (Włodarczyk, 1983; Dobrzański, 2009).

Among the poisonous species commonly found in meadows and pastures are representatives of the Ranunculaceae Juss. family. Buttercups contain poisonous glycosides and alkaloids, which are dangerous to animals. There are relatively many on pastures, as they are left by grazing cattle (Nowiński, 1970). For the plots in the Wadowice commune grassland that was analysed, Ranunculus acris occurred in all four groups of meadows (Appendix 1 - Tab. 1-4). In group I with Phleum pratense and Vicia cracca, buttercup was present in only 3 plots, and in the other groups it occurred frequently but with low coverage - usually from + to $2 \%$ (sporadically $5-10 \%$ ). Of note, buttercups are dangerous for animals only when fresh. Most often poisoning occurs in the spring, when only its leaves are present in the sward. When flowers appear, 
the animals bypass this plant. In hay, buttercups lose their toxic properties and are not dangerous (Nawara, 2012).

Stellaria graminea is another toxic species. Chickweed belongs to the Caryophyllaceae Juss. family, and its herb is particularly dangerous for animals (Grynia, 1974). However, the share of chickweed found in the analysed plots was insignificant - in groups II and III it sporadically covers up to $5 \%$ and in other groups up to $2 \%$ (Appendix 1 - Tab. 1-4). Other undesirable species in the meadows include Rumex acetosa (Polygonaceae Juss.), Veronica chamaedrys (Scrophulariaceae Juss.), Equisetum arvense, and E. palustre (Equisetaceae Michx. ex DC.) (Nowiński, 1970; Nawara, 2012). Their share in the studied area was relatively small (up to $2 \%$ ), thus not of great importance for the overall usage value of the analysed plots. Only sorrel sporadically reached coverage of up to 5\% in the group II plots with Holcus lanatus (Appendix 1 - Tab. 2). It is characterised by a high content of calcium oxalate, which is deposited in the organs. Horsetails, in addition to being hard due to the presence of silica, also contain substances that have a toxic effect on the functioning of organisms (Grynia, 1974). The larger share of these plants in the plots may be the result of being bypassed by grazing animals.

Similarly, the rushes Juncus effusus or J. inflexus (Juncaceae Juss.) are species clearly bypassed by animals due to the hardness of the stems. In the presence of intensive defoliation of fodder plants and trampling, to which the rushes are quite resistant, they can colonise the habitat without major barriers (Barabasz, 1994). Strong growth of rhizomes and high durability of seeds (even up to 60 years) makes competition of other plants with rushes very difficult (Nowiński, 1970). However, this unfavourable phenomenon was not observed in the study area, as rushes occurred here relatively rarely and with low coverage up to 5\% (Appendix $1-$ Tab. 1-4). It is worth noting that rushes belong to the group of weeds that make mowing difficult (Włodarczyk, 1983).

In some of the study plots, mainly in the first group, weeds characteristic of arable fields also occurred: Papaver rhoeas, Matricaria maritima ssp. inodora, or Agrostemma githago (Appendix 1 - Tab. 1). Their presence indicates the close proximity of the studied meadows to arable fields, or they may be a remnant of former crops that have since been converted to grassland (Barabasz-Krasny, 2011). Cultivated weeds can easily infiltrate neighbouring areas and, although they are quite sensitive to other habitat conditions, they persist quite well on the outskirts of meadows, where the sward is not so dense (Dubiel, 1984). According to Picket and Cadenasso (2005), the remainder of the last crop (some weeds) can be observed in plant communities for about 10 years after the crop has been abandoned.

For proper management of grasslands, the care of meadows and pastures is just as important as rational usage (Falkowski, 1983; Aldrich, 1984; Teague et al., 2011). For example, a weakly compact sward is bad for young grasses and plants that are poorly 
rooted in soil. Meanwhile, if a sward is too dense it degrades and reduces the yield of the meadow (Adler et al., 2001). Both mounds of moles and the accumulation of animal droppings cause gaps in the continuity of meadow sward. Therefore, plants in these types of areas, although they grow luxuriantly, are bypassed and reluctantly eaten by animals due to the unpleasant smell (Kocan, Jacniacki, 1980). As a result, weeds of the meadow sward are favoured and species such as thistle (Cirsium sp. Asteraceae Dum.) and nettle Urtica dioica (Urticaceae Juss.) begin to appear (Nowiński, 1970; Dobrzański, 2009). In this study area, the share of these types of weeds was relatively small (Appendix 1 - Tab. 1-4).

However, in the analysed meadows, a fairly large group of plants were weeds, the addition of which is beneficial for animals. For example, the presence of up to $5 \%$ coverage of species such as Achillea millefolium, Alchemilla monticola, Taraxacum officinale, Plantago major, or P. lanceolata increases the usage value of meadows and pastures. Yarrow improves the digestion of animals, and lady's mantle has many nutrients and positive effects on milk quality. Dandelion is also a fodder herb and has medicinal properties. However, in large quantities, just like plantains, lady's mantle, and yarrow, it can be poisonous to animals (Nowiński, 1970; Nawara, 2012). A. monticola occurred at an appropriate level in the study area in group II plots, some of which are used as pastures. The exception was 1 plot of this group, where it reached $10 \%$ coverage. Similarly, P. major occurred at a level above $5 \%$ only in 1 plot of each group, and P. lanceolata occurred in group II and III in 2 plots and 1 plot, respectively. T. officinale, found in 15 plots from all four groups, also had a larger share, 10-20\% of coverage (Appendix 1 - Tab. 1-4). Similarly, A. millefolium occurred in as many as 10 plots, also with high coverage. Hence, it would be worth undertaking actions to balance the share of these plants in some plots.

Research indicates that direct weed control with chemicals has a worse effect on meadows and pastures than slower but thoughtful and rational prevention of their spread (Falkowski, 1983; Heap, 2014). Incorrect usage promotes larger concentrations of weeds and weakens meadows sward. Both an excess or a deficiency in grazing and mowing adversely affect the meadows (Kornaś, 1990; Barabasz, 1994; Załuski, 2002; Bator, 2005; Kompała-Bąba, Bąba, 2007; Díaz et al., 2007; Pauler et al., 2019). The improvement of species composition can be achieved by proper mowing, which prevents the flowering phase of some undesirable species. Moderate grazing can also contribute to improving the quality of the meadow, as it helps in the mechanical removal of harmful plants, as mentioned previously.

The most favourable composition of meadow sward in the study area occurred in plots included in group IV with Arrhenatherum elatius (Appendix 1 - Tab. 4, Fig. 4). There was a fairly good proportion of legumes, which was also reflected in the usage values of those plots, whose average UVM was at a good level (Appendix 1 - 
Tab. 6). In addition to false oat-grass, other forage grasses were abundant here: Phleum pratense, Dactylis glomerata and Poa pratensis. These species are characterised by high usage value and fertility. They are the most desirable grass species in grassland (Jagła, 2001; Nawara, 2012). Tall grasses, such as cocksfoot, timothy, or false oat-grass, are more common in meadow areas because they tolerate mowing better than being trampled and bitten by grazing animals (Barabasz, 1994). They are usually associated with relatively fertile places, which can also be seen in the study area (Appendix 1 - Tab. 5). They are excellent for fodder, both fresh and in the form of hay. Bluegrass is even more valuable, additionally resistant to various unfavourable habitat factors and giving high yields. It prefers medium or high humidity and fertile environments (Falkowski, 1983).

On the other hand, group III with Holcus lanatus had the relatively weakest usage value in the analysed commune - the fewest number of plots of good usable quality were noted here (Appendix 1 - Tab. 6; Fig. 4). The velvet grass that dominates here has a fairly low fodder value as it is not suitable for animal feed because of its hairy stalks. Its hay is also too tomentose and slight (Nawara, 2012). However, in this group there are also species such as Poa pratensis or Arrhenatheretum elatius, as well as legume species that help to maintain the usage value at an average level (Appendix 1 - Tab. 3).

Observations carried out during field studies confirm the fact that in the analysed area, the meadow management was rather balanced, although care treatments would certainly improve the usage values of many meadow plots. To improve the quality of meadows and pastures, care should be taken to ensure proper conditions for high-quality plants and to reduce undesirable species. Most often, these type of management methods include maintaining the compactness of the turf (so that it is not too loose or compact); cleaning works in sward - clearing mounds of mole; removing animal droppings; removing weeds; as well as rational mowing and grazing. Properly fertilised soil can also contribute to an increase in crops - fertilisation with nitrogen, phosphorus, and potassium, especially in the case of grasses, and fertilisation with magnesium, in the case of legumes. Care should be spread over time - cleaning work in autumn and fertilisation and care for proper drainage management in early spring (Falkowski, 1983; Kocan, Jacniacki, 1980).

\section{Conclusions}

(1), (2) On the basis of floristic analyses, it can be stated that the species composition was found to be quite diverse in utility meadows and pastures of Wadowice commune; they can be classified as moderately sunny meadows, with average soil moisture (fresh), slightly acidic, and quite rich in nitrogen. (3) The studied grasslands had average (groups: I with Phleum pratense and Vicia cracca, II with Dactylis glomerata and 
Trifolium repens, III with Holcus lanatus) and good (group IV with Arrhentherum elatius) usage values. Balanced fertilisation could increase the usage value of the meadows and pastures examined. However, the improvement of the quality of the botanical composition of medium fodder value plots could be achieved through appropriate comprehensive care and sustainable use.

\section{Conflict of interest}

The author declares no conflict of interest related to this article.

\section{References}

Adler, P., Raff, D., Lauenroth, W. (2001). The effect of grazing on the spatial heterogeneity of vegetation. Oecologia, 128, 465-479. https://doi.org/10.1007/s004420100737

Aldrich, R.J. (1984). Crop production practices and weeds. In: R.J. Aldrich (ed.), Weed crop ecology. Principles in weed management. p. 373-397. North Scituate, MA: Breton Publ.

Bakker, J.P., Berendse, F. (1999). Constraints in the restoration of ecological diversity in grassland and heather communities. Trends in Ecology and Evolution, 14, 63-68. https://doi.org/10.1016/S01695347(98)01544-4

Barabasz, B. (1994). Wpływ modyfikacji tradycyjnych metod gospodarowania na przemiany roślinności łąk z klasy Molinio-Arrhenatheretea (The impact of modification of traditional farming methods on the transformation of vegetation of meadows of the Molinio-Arrhenatheretea class). Wiadomości Botaniczne, 38(1/2), 85-94. [In Polish]

Barabasz-Krasny, B. (2011). Zróżnicowanie roślinności i sukcesja wtórna na odłogach wielkopowierzchniowych Pogórza Przemyskiego (Vegetation diversity and secondary succession on the fallow land of the Przemyśl Foothills). Kraków: Instytut Botaniki im. W. Szafera PAN, pp. 180. [In Polish]

Bator, I. (2005). Stan obecny i przemiany zbiorowisk łąkowych okolic Mogilan (Pogórze Wielickie) w okresie 40 lat (The present state and changes of meadow communities in the vicinity of Mogilany (Pogórze Wielickie) over the period of 40 years). Fragmenta Floristica et Geobotanica Polonica, 7(Suppl.), 97. [In Polish]

Bednarek, R., Skiba, S. (2015). Geografia gleb Polski (The geography of Polish soils). In: A. Mocek (ed.), Gleboznawstwo. Wyd. I. Warszawa: PWN, s. 411-418. [In Polish]

Bobbink, R., Hornung, M., Roelofs, J.G.M. (1998). The effect of air-borne nitrogen pollutants on species diversity in natural and semi-natural European vegetation - a review. Journal of Ecology, 86, 717-738. https://doi.org/10.1046/j.1365-2745.1998.8650717.x

Díaz, S., Lavorel S., McIntyre, S., Falczuk, V., Casanoves, F., Milchunas, D.G., Skarpe, C., Rusch, G., Sternberg, M., Noy-Meir, I., Landsberg, J., Zhang, W., Clark, H., Campbell, B.D. (2007). Plant trait responses to grazing - a global synthesis. Global Change Biology, 13, 313-341. https://doi.org/10.1111/j.13652486.2006.01288.x

Dobrzański, A. (2009). Biologiczne i agrotechniczne aspekty regulowania zachwaszczenia. Ekspertyza. (Biological and agrotechnical aspects of weed infestation regulation. Expertise). Instytut Warzywnictwa Skierniewice, ss. 24. AgEngPol (www.agengpol.pl). [In Polish]

Dubiel, E. (1984). Dolina Wierzbanówki: 5. Rozwój roślinności na odłogach (Wierzbanówka Valley: 5. The development of vegetation on fallow land). Prace Botaniczne, 12, 97-111. [In Polish]

Dzwonko, Z. (2007). Przewodnik do badań fitosocjologicznych (Guide to phytosociological research). Poznań-Kraków: Sorus. [In Polish]

Ellenberg, H., Weber, H., Dull, R., Wirth, V., Werner, W., Paulissen, D. (1992). Zegerverte von Pflanzen in 
Mitteleuropa (Zegerverte of plants in Central Europe). Scripta Geobotanica, 18, 1-258. [In German]

Falkowski, M. (1983). Łąkarstwo i gospodarka łakowa (Grassland and meadow management). Warszawa: PWRiL, pp. 615. [In Polish]

Filipek, J. (1973). Projekt klasyfikacji roślin łąkowych i pastwiskowych na podstawie liczby wartości użytkowej (Project of classification of meadow and pasture plants based on the number of utility value). Postępy Nauk Rolniczych, 4, 59-68. [In Polish]

Grynia, M. (1974). Trujące i szkodliwe rośliny łąk i pastwisk (Poisonous and harmful plants of meadows and pastures). Poznań: PWRiL, pp. 127. [In Polish]

Haghighi, F., Gorji, M., Shorafa, M. (2010). A study of the effects of land use changes on soil physical properties and organic matter. Land Degradation \& Development, 21(5), 496-502. https://doi. org/10.1002/ldr.999

Heap, I.M. (2014). Herbicide resistant weeds. In: D. Pimentel, R. Peshin (eds.), Pesticide problems. Integrated pest management, 3, 281-301. The Netherlands: Springer, Dordrecht.

Hess, M. (1965). Piętra klimatyczne w polskich Karpatach Zachodnich (Climatic floors in the Polish Western Carpathians). Zeszyty Naukowe Uniwersytetu Jagiellońskiego. Prace Geograficzne, 11, 1-258. [In Polish]

Jagła, S. (2001). Dominujące zbiorowiska roślinne górskich użytków zielonych i ich wartość paszowa (Dominant plant communities of mountain grasslands and their fodder value). In: H. Jankowska-Huflejt, J. Zastawny (eds.), Niskonakładowa produkcja rolnicza $z$ wykorzystaniem pasz z użytków zielonych $w$ Karpatach Polskich. Raszyn: Wydawnictwo IMUZ, Falenty. [In Polish]

Klapp, E. (1962). Łąki i pastwiska (Meadows and pastures). Warszawa: PWRiL, pp. 600. [In Polish]

Kocan, T., Jacniacki, K. (1980). Uprawa łąk i pastwisk (Growing meadows and pastures). Warszawa: PWRiL, pp. 282. [In Polish]

Kompała-Bąba, A., Bąba, W. (2007). Przemiany składu florystycznego zbiorowisk łąkowych kotliny dąbrowskiej (wyżyna śląska) jako wynik zaprzestania tradycyjnych form użytkowania i degradacji środowiska (Changes in the floristic composition of meadow communities in the Dąbrowa Ba$\sin$ (Silesian Upland) as a result of the cessation of traditional forms of use and environmental degradation). Acta Botanica Warmiae et Masuriae, 4, 173-186. [In Polish]

Kondracki, J. (2011). Geografia regionalna Polski (Regional geography of Poland). Warszawa: PWN, pp. 440. [In Polish]

Kornaś, J. (1990). Jak i dlaczego giną nasze zespoły roślinne (How and why our plant communities are dying). Wiadomości Botaniczne, 34(2), 7-16. [In Polish]

Kornaś, J., Dubiel, E. (1991). Land use and vegetation changes in hay-meadow in the Ojców National Park during last thirty years. Veröffentlichungen des Geobotanischen Institutes der Eidg. Techn. Hochschule, Stiftung Rübel, in Zürich, 106, 209-231.

Local Development Strategy for rural areas of the Wadowice and Andrychów Communes for the years 2009-2015. (Lokalna Strategia Rozwoju dla obszarów wiejskich Gminy Wadowice i Andrychów na lata 2009-2015). (2014), Wadowice. [In Polish]

Łyszczarz, R. (2014). LWU i WUŁ czyli prawie wszystko zależy od składu botanicznego. Hodowca bydła, 4. http://www.portalhodowcy.pl/611-lwu-i-wul-czyli-prawie-wszystko-zalezy-od-skladu-botanicznego

Mirek, Z., Piękoś-Mirkowa, H., Zając A., Zając M. (2002). Flowering plants and Pteridophytes of Poland a checklist. Kraków: Władysław Szafer Institute of Botany, PAN, pp. 442.

Nawara, Z. (2012). Rośliny ląk (Meadow plants). Warszawa: Multico, pp. 272. [In Polish]

Nowiński, M. (1970). Chwasty łąk i pastwisk (Weeds of meadows and pastures). Warszawa: PWRiL, pp. 
412. [In Polish]

Pauler, C.M., Isselstein, J., Braunbeck, T., Schneider, M.K. (2019). Influence of highland and production-oriented cattle breeds on pasture vegetation: A pairwise assessment across broad environmental gradients. Agriculture, Ecosystems \& Environment, 284, 106585. https://doi.org/10.1016/j. agee.2019.106585

Pickett, S.T.A., Cadenasso, M.L. (2005). Vegetation dynamics. In: E. van der Maarel (ed.), Vegetation Ecology, p. 172-198. Malden: Blackwell Science Ltd.

Radkowski, A., Barabasz-Krasny, B. (2008). Ugrupowania nitrofitów na powierzchni utylizacji siana w Stacji Hodowli Roślin Skrzeszowice (Nitrophyte groups on the hay utilisation area at the Skrzeszowice Plant Breeding Station). Łąkarstwo w Polsce, 11, 157-166. [In Polish]

Roo-Zielińska, E. (2014). Wskaźniki ekologiczne zespołów roślinnych Polski (Ecological indicators of Polish plant communities). Warszawa: SEDNO, pp. 387. [In Polish]

Siemionow, A. (1984). Ziemia Wadowicka (The Wadowice Land). Kraków: Wydawnictwo im. W.L. Anczyca, pp. 626. [In Polish]

Sienkiewicz, J. (2010). Koncepcje bioróżnorodności - ich wymiary i miary w świetle literatury (Concepts of biodiversity - their dimensions and measures in the light of literature). Ochrona Środowiska $i$ Zasobów Naturalnych, 45, 17-20. [In Polish]

Szafer, W., Kulczyński, S., Pawłowski, B. (1986). Rośliny polskie. Opisy i klucze do oznaczania wszystkich gatunków roślin naczyniowych rosnących w Polsce bądź dziko, bądź też zdziczałych lub częściej hodowanych (Polish plants. Descriptions and identification keys for all species of vascular plants growing in Poland either in the wild, or wild or more frequently bred). I, II,. Warszawa: PWN, pp. 1020. [In Polish]

Teague, W.R., Dowhower, S.L., Baker, S.A., Haile, N., DeLaune, P.B., Conovera, D.M. (2011). Grazing management impacts on vegetation, soil biota and soil chemical, physical and hydrological properties in tall grass prairie. Agriculture, Ecosystems \& Environment, 141, 3-4, 310-322. https://doi. org/10.1016/j.agee.2011.03.009

Westhoff, V., van der Maarel, E. (1978). The Braun-Blanquet approach. In: R.H. Wittaker (ed.), Classification of plant communities, Hague: Junk, p. 287-399.

Wildi, O., Orlóci, L. (1996). Numerical exploration of community patterns. A guide to use of MULVA-5. The Hague: SPB Academic Publishing, pp. 171.

Włodarczyk, S. (1983). Botanika łąarska (Grassland botany). Warszawa: PWRiL, pp. 239. [In Polish]

Woś, A. (1999). Klimat Polski. Warszawa: PWN, pp. 301. [In Polish]

Załuski, T. (2002). Zagrożenia i ochrona zespołów trawiastych (Threats and protection of grasslands). In: L. Frey (ed.), Polska Ksiega Traw. Prace Zbiorowe. Kraków: Instytut Botaniki im. Władysława Szafera PAN p. 245-247. [In Polish]

Zarzycki, J. (2009). Metodyczne i techniczne innowacje w badaniach fitosocjologicznych (Methodical and technical innovations in phytosociological research). Łąkarstwo w Polsce, 12, 233-247. [In Polish] 
Tab. 1. Group I - plots with Phleum pratense and Vicia cracca

\begin{tabular}{llllllllllllllllll}
\hline Successive No. of plots & 1 & 2 & 3 & 4 & 5 & 6 & 7 & 8 & 9 & 10 & 11 & 12 & 13 & 14 & 15 & 16
\end{tabular} $\begin{array}{llllllllllllllllllllll}\text { No. plot in the area } & 34 & 27 & 33 & 49 & 43 & 46 & 32 & 41 & 18 & 13 & 4 & 19 & 42 & 14 & 35 & 8 \\ \text { Number of } \\ \text { occurrence }\end{array}$

$\begin{array}{llllllllllllllll}\text { Number of species in plot } 11 & 12 & 10 & 8 & 14 & 9 & 13 & 9 & 12 & 14 & 13 & 15 & 14 & 12 & 11 & 13\end{array}$

Grass

Phleum pratense

\begin{tabular}{|c|c|c|c|c|c|c|c|c|c|c|c|c|}
\hline 10 & 35 & 30 & 2 & 10 & 10 & 35 & 5 & 40 & & 2 & & \\
\hline 20 & 10 & . & 2 & 10 & 10 & 10 & 2 & 10 & & & & \\
\hline 8 & . & 10 & . & $\cdot$ & . & 10 & 1 & 10 & 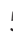 & & & . \\
\hline . & . & 5 & 2 & . & . & . & 10 & & 2 & & & 35 \\
\hline & 10 & 2 & 15 & 25 & . & 20 & & & & & & 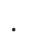 \\
\hline & . & . & 60 & 10 & 40 & . & & & & & 10 & \\
\hline
\end{tabular}

Poa pratensis

Anthoxanthum odoratum

Arrhenatherum elatius

Dactylis glomerata

Alopecurus pratensis

$\begin{array}{lll}60 & 10 & 40\end{array}$

\begin{tabular}{|c|c|c|c|c|c|c|c|c|c|c|c|c|c|c|c|}
\hline 0 & 10 & 30 & & 10 & 2 & 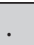 & 2 & 2 & 1 & & 2 & 10 & 10 & 10 & + \\
\hline 10 & 10 & & 15 & 2 & 2 & 2 & $\dot{\square}$ & $\dot{\square}$ & $\cdot$ & 5 & $\dot{.}$ & 1 & & . & . \\
\hline - & . & 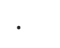 & . & 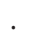 & 25 & . & 10 & 20 & 30 & 40 & 10 & 25 & & & 20 \\
\hline · & 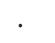 & & 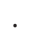 & . & . & . & 50 & 10 & 25 & 5 & . & - & & & \\
\hline . & . & . & . & . & . & . & & & & 5 & 10 & & 10 & & \\
\hline
\end{tabular}

Legumes

Vicia cracca

Lathyrus pratensis

Trifolium pratense

T. repens

Medicago lupulina

Others

Taraxacum officinale

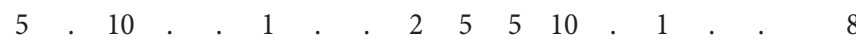

Plantago major

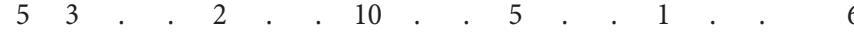

Aegopodium podagraria

Papaver rhoeas

Matricaria maritima ssp.

inodora

Symphytum officinale

Centaurea jacea

Achillea millefolium

Rumex acetosa

Equisetum arvense

Cirsium rivulare

Stellaria graminea

Hypericum perforatum

Leontodon hispidus

Ranunculus acris

Urtica dioica

Cirsium arvense

Capsella bursa-pastoris

$+.2+108.2$

Convolvulus arvensis

Potentilla anserina

Plantago lanceolata 
Lychnis flos-cuculi

Chamomilla recutita

Myosotis arvensis

Sporadic species - Grass: Phragmites australis 32: 1; Elymus repens 13: 5; Trisetum flavescens 35: 25. Others: Campanula patula 27: +; Geranium dissectum 33: +; Galium aparine 43: 10; Mentha longifolia 43: 10; Oxalis acetosella 32: 2; Solidago gigantea 32: 8; Veronica chamaedrys 18: +; Ajuga reptans 13: +; Campanula trachelium 4: +; Agrimonia eupatoria 19: +; Armoratia rusticana 19: 2; Artemisia vulgaris 19: 2; Agrostemma githago 42: +; Daucus carota 8: 2; Galium mollugo 8: 10; Juncus effusus 8: 2; Lysymachia vulgaris 8: 10. 
Tab. 2. Group II - plots with Dactylis glomerata and Trifolium repens

\begin{tabular}{|c|c|c|c|c|c|c|c|c|c|c|c|c|c|}
\hline Successive No. of plots & 1 & 2 & 3 & 4 & 5 & 6 & 7 & 8 & 9 & 10 & 11 & 12 & \multirow{3}{*}{$\begin{array}{l}\text { Number of } \\
\text { occurrence }\end{array}$} \\
\hline No. plot in the area & 40 & 7 & 48 & 37 & 26 & 5 & 22 & 29 & 28 & 23 & 21 & 36 & \\
\hline Number of species in plot & 12 & 12 & 14 & 16 & 14 & 17 & 13 & 13 & 17 & 13 & 19 & 12 & \\
\hline \multicolumn{14}{|l|}{ Grasses } \\
\hline Dactylis glomerata & 15 & 10 & 30 & 10 & 40 & 30 & 15 & 40 & 40 & 20 & 15 & 10 & 12 \\
\hline Poa pratensis & 60 & 40 & 10 & 10 & 5 & 20 & 5 & . & . & 10 & 5 & 10 & 10 \\
\hline Alopecurus pratensis & . & . & 10 & 20 & . & . & 15 & . & . & 2 & 1 & . & 5 \\
\hline Phleum pratense & . & . & . & . & . & . & . & 10 & 2 & 5 & 5 & 25 & 5 \\
\hline Festuca pratensis & . & . & . & . & 10 & . & . & . & 10 & 10 & 5 & . & 4 \\
\hline Holcus lanatus & . & 5 & . & . & . & . & 1 & . & . & . & . & . & 2 \\
\hline Anthoxanthum odoratum & . & . & . & 5 & . & 5 & . & . & . & . & . & . & 2 \\
\hline \multicolumn{14}{|l|}{ Legumes } \\
\hline Trifolium repens & 2 & 10 & 5 & 30 & 10 & 8 & 5 & 10 & 10 & 20 & 15 & 10 & 12 \\
\hline T. pratense & . & . & 5 & 5 & 10 & 5 & 15 & . & 10 & . & . & 10 & 7 \\
\hline Vicia cracca & 2 & . & . & . & + & 5 & . & 2 & 2 & . & . & . & 5 \\
\hline Medicago lupulina & 2 & . & . & 1 & + & . & . & . & . & . & . & 2 & 4 \\
\hline Lathyrus pratensis & . & . & . & . & . & . & . & 2 & 2 & . & . & . & 2 \\
\hline \multicolumn{14}{|l|}{ Others } \\
\hline Ranunculus acris & + & 1 & + & 1 & 1 & 1 & 5 & 2 & + & . & 10 & + & 11 \\
\hline Taraxacum officinale & 10 & 10 & 10 & 5 & 10 & . & . & 2 & 2 & 2 & 15 & 10 & 10 \\
\hline Plantago lanceolata & . & 10 & 1 & 5 & 1 & 5 & . & . & . & . & 15 & . & 6 \\
\hline Alchemilla monticola & . & . & 10 & + & . & . & 1 & 2 & 2 & . & + & . & 6 \\
\hline Achillea millefolium & . & . & . & 1 & 5 & 5 & 5 & 2 & 2 & . & . & . & 6 \\
\hline Rumex acetosa & . & . & . & . & . & 5 & + & 1 & 2 & 5 & 1 & . & 6 \\
\hline Equisetum arvense & . & + & . & . & + & 1 & . & . & + & . & + & . & 5 \\
\hline Aegopodium podagraria & . & . & . & 1 & . & 1 & . & . & . & 20 & 5 & 2 & 5 \\
\hline Stellaria graminea & 2 & . & 5 & . & . & 1 & . & . & . & . & + & . & 4 \\
\hline Plantago major & . & 10 & 5 & 1 & 5 & . & . & . & . & . & . & . & 4 \\
\hline Cirsium rivulare & . & . & $\cdot$ & . & . & . & 5 & 25 & 10 & . & 5 & . & 4 \\
\hline Galium mollugo & . & . & . & . & . & . & . & 1 & 2 & 2 & . & 10 & 4 \\
\hline Capsella bursa-pastoris & 2 & . & . & . & . & . & 1 & . & . & 2 & . & . & 3 \\
\hline Veronica chamaedrys & . & . & . & + & . & + & . & . & . & 2 & . & . & 3 \\
\hline Urtica dioica & 1 & 1 & . & . & . & . & . & . & . & . & . & . & 2 \\
\hline Matricaria maritima ssp. inodora & 2 & . & . & . & . & . & 25 & . & . & . & . & . & 2 \\
\hline Myosotis palustris & + & . & . & . & . & . & . & . & . & . & + & . & 2 \\
\hline Glechoma hederacea & . & . & 5 & 1 & . & . & . & . & . & . & . & . & 2 \\
\hline Campanula patula & . & . & 1 & . & . & + & . & . & . & . & . & . & 2 \\
\hline Potentilla anserina & . & . & . & . & . & . & . & 2 & 2 & . & . & . & 2 \\
\hline Lychnis flos-cuculi & . & . & . & . & . & . & . & . & . & 2 & + & . & 2 \\
\hline
\end{tabular}

Sporadic species - Grasses: Arrhenatherum elatius 48: 1. Others: Ranunculus repens 7: +; Symphytum officinale 7: 1; Petasites albus 26: +; Juncus inflexus 5: 5; Pteridium aquilinum 5: +; Oxalis acetosella 28: 2; Galium aparine 21: +; Dactylorhiza majalis 21: +; Convolvulus arvensis 36: 2; Armoratia rusticana 36: 10. 
Tab. 3. Group III - plots with Holcus lanatus

\begin{tabular}{|c|c|c|c|c|c|c|c|c|}
\hline Successive No. of plots & 1 & 2 & 3 & 4 & 5 & 6 & 7 & \multirow{3}{*}{$\begin{array}{l}\text { Number of } \\
\text { occurrence }\end{array}$} \\
\hline No. plot in the area & 31 & 30 & 11 & 6 & 25 & 50 & 24 & \\
\hline Number of species in plot & 14 & 16 & 14 & 12 & 15 & 13 & 15 & \\
\hline \multicolumn{9}{|l|}{ Grasses } \\
\hline Holcus lanatus & 30 & 30 & 30 & 20 & 10 & 30 & 35 & 7 \\
\hline Poa pratensis & 5 & 8 & 2 & 10 & 35 & . & 5 & 6 \\
\hline Arrhenatherum elatius & 10 & 10 & 5 & 30 & . & . & . & 4 \\
\hline Dactylis glomerata & . & . & 10 & . & . & 2 & . & 2 \\
\hline \multicolumn{9}{|l|}{ Legumes } \\
\hline Vicia cracca & 1 & 1 & . & 5 & 2 & 1 & + & 6 \\
\hline Trifolium pratense & . & . & 20 & 1 & 5 & 10 & 5 & 5 \\
\hline T. repens & 20 & 20 & . & . & . & 30 & 8 & 4 \\
\hline Lathyrus pratensis & . & . & 10 & 10 & 10 & . & . & 3 \\
\hline Medicago lupulina & . & . & . & 5 & . & . & 2 & 2 \\
\hline \multicolumn{9}{|l|}{ Others } \\
\hline Ranunculus acris & 1 & 2 & 1 & 10 & 2 & . & . & 5 \\
\hline Taraxacum officinale & 20 & 10 & 5 & 1 & 10 & . & . & 5 \\
\hline Plantago major & 5 & 10 & 5 & . & 5 & 2 & . & 5 \\
\hline Leontodon hispidus & 1 & 1 & . & . & + & 1 & 10 & 5 \\
\hline Plantago lanceolata & . & . & 5 & 5 & 5 & 1 & 10 & 5 \\
\hline Stellaria graminea & + & 5 & . & + & 2 & . & 2 & 5 \\
\hline Veronica chamaedrys & + & 1 & . & . & 2 & 1 & . & 4 \\
\hline Achillea millefolium & . & . & 1 & . & 10 & . & 20 & 3 \\
\hline Chamomilla recutita & 1 & 1 & . & . & . & . & 2 & 3 \\
\hline Matricaria maritima ssp. inodora & 1 & 1 & . & . & . & . & . & 2 \\
\hline Viola arvensis & . & + & . & . & . & . & + & 2 \\
\hline Rumex acetosa & . & . & 2 & . & + & . & . & 2 \\
\hline Aegopodium podagraria & . & . & 1 & . & . & 10 & . & 2 \\
\hline Equisetum arvense & . & . & . & . & . & + & + & 2 \\
\hline
\end{tabular}

Sporadic species - Grasses: Lolium perenne 31: 1; Elymus repens 11: 1; Phleum pratense 50: 10. Others: Centaurea jacea 30: +; Oxalis fontana 30: +; Senecio jacobaea 6: +; Galium mollugo 25: 2; Lychnis flos-cuculi 50: +; Agrimonia eupatoria 24: +; Juncus effusus 24: +. 
Tab. 4. Group IV - plots with Arrhenatherum elatius

Grasses

Arrhenatherum elatius

$\begin{array}{lllllllllllllllll}10 & 30 & 30 & 20 & 40 & 10 & 10 & 30 & 50 & 10 & 20 & 10 & 10 & 10 & 15 & 20 & 16\end{array}$

Phleum pratense

$\begin{array}{lllllllllllllllll}10 & 10 & 10 & . & 1 & . & . & 10 & 10 & 2 & 10 & 10 & 10 & 10 & 10 & 10 & 13\end{array}$

Dactylis glomerata

$\begin{array}{llllllllllllllllll}10 & 10 & 10 & 30 & 10 & 35 & 60 & . & . & . & . & 20 & 10 & 40 & 10 & 10 & 12\end{array}$

Poa pratensis

Anthoxanthum odoratum

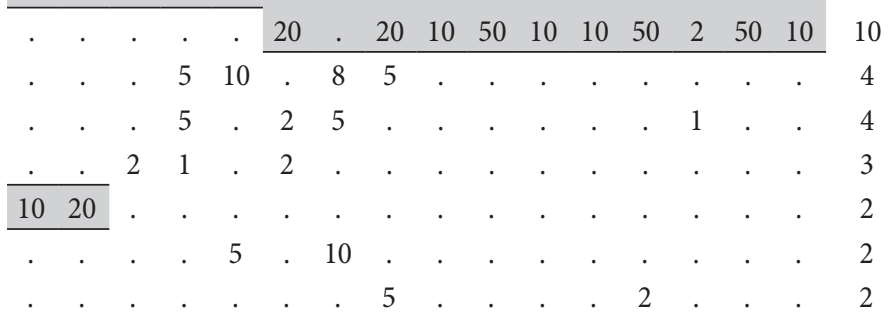

Holcus lanatus

Elymus repens

Lolium perenne

Festuca pratensis

Alopecurus pratensis

Legumes

Vicia cracca

Trifolium repens

T. pratense

Medicago lupulina

Lathyrus pratensis

\begin{tabular}{ccccccccccccccccc}
10 & 1 & 2 & 1 & 1 & 10 &. & 1 & 10 &. & 2 &. & 2 & 1 &. &. & 11 \\
\hline 30 &. & 5 & 20 & 10 &. &. & 5 &. & 5 & 10 &. &. &. &. &. & 7 \\
\hline. &. &. &. & 1 &. &. & 5 &. & 10 &. & 25 & 10 &. &. &. & 5 \\
. &. & 5 &. &. &. &. &. &. & 10 & 20 &. &. &. &. &. & 5 \\
. & 10 &. &. &. &. &. &. &. & 10 & 20 &. &. &. &. &. & 3 \\
& 10 &. &. &. &. &. &. &. &. &. &. & 2 &. &. &. & 2
\end{tabular}

Others

Achillea millefolium

$\begin{array}{lllllllllllllllll}5 & 15 & 10 & 5 & 1 & 5 & 2 & 5 & 2 & . & 2 & 2 & 2 & 10 & 2 & 10 & 15\end{array}$

Ranunculus acris

Taraxacum officinale

Stellaria graminea

Lychnis flos-cuculi

Veronica chamaedrys

Rumex acetosa

Plantago major

Aegopodium podagraria

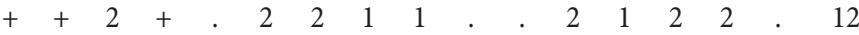

Equisetum arvense

Plantago lanceolata

Campanula patula

Mentha longifolia

Hypericum perforatum

Equisetum palustre

Convolvulus arvensis

Potentilla anserina

Myosotis palustris

Senecio jacobaea

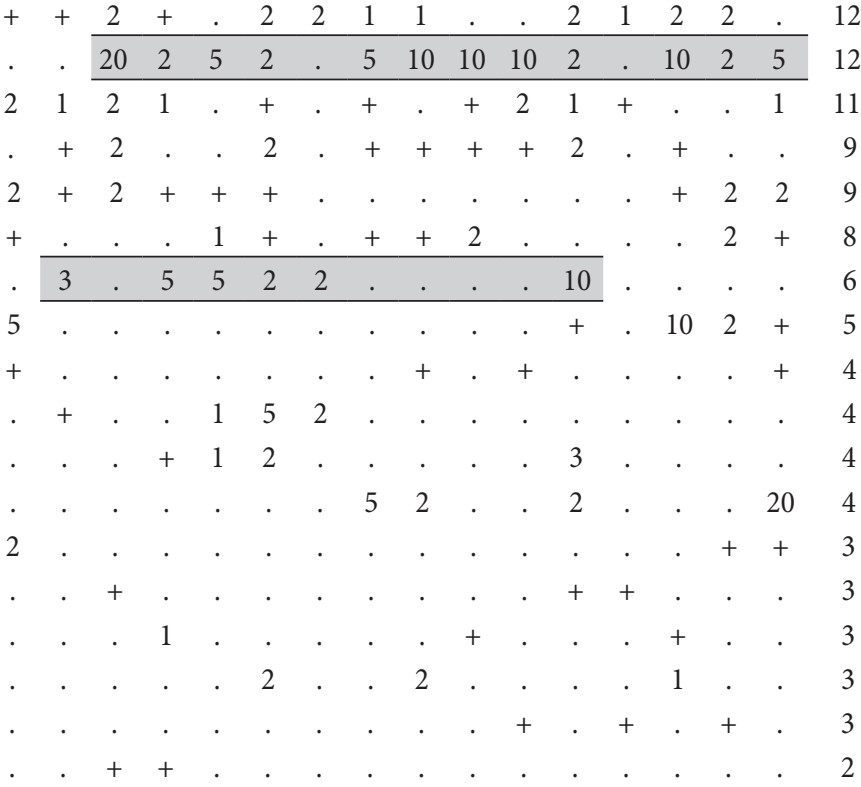




\begin{tabular}{|c|c|c|c|c|c|c|c|c|c|c|c|}
\hline Viola arvensis & e & $\cdot \quad+$ & & . & . & . & + & $\cdot$ & . & . & 2 \\
\hline Juncus effusus & . & . & 1 & 2 & . & . & . & . & . & . & . \\
\hline Alchemilla monticola & . & . & . & . & . 1 & . & . & 2 & . & . & . \\
\hline $\begin{array}{l}\text { Matricaria maritima ssp. } \\
\text { inodora }\end{array}$ & . & . & . & $\cdot$ & . & . & 2 & 1 & . & . & . \\
\hline Geranium dissectum & . & . & . & . & . & . & 2 & . & . & . & + \\
\hline Urtica dioica &.$\quad$. & . $\quad$. & . & . & . . &.$\quad$. & . & . & . 2 & + & . \\
\hline
\end{tabular}


Tab. 5. Comparison of average values of Ellenberg's indicators (L, F, R, N) calculated for groups of plots distinguished on the studied area of the Wadowice commune; grey colour indicates the highest values

\begin{tabular}{|c|c|c|c|c|c|c|}
\hline \multirow[b]{2}{*}{ Group name } & \multirow{2}{*}{ 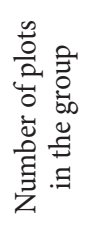 } & \multirow[b]{2}{*}{$\begin{array}{c}\text { Average number } \\
\text { of species in plot } \\
\pm S D\end{array}$} & \multicolumn{4}{|c|}{$\begin{array}{c}\text { Ellenberg's indicators } \\
\text { (average values and ranges) }\end{array}$} \\
\hline & & & 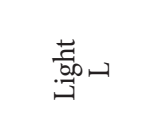 & 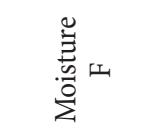 & 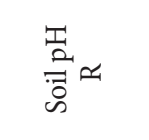 & 营 \\
\hline $\begin{array}{l}\text { - plots with Phleum } \\
\text { atense and Vicia crac- }\end{array}$ & 16 & $12 \pm 2$. & $\begin{array}{c}6.91 \\
(6.41-7.50)\end{array}$ & $\begin{array}{c}5.40 \\
(5.00-5.96)\end{array}$ & $\begin{array}{c}6.38 \\
(5.57-7.09)\end{array}$ & $\begin{array}{c}6.49 \\
(5.89-7.08)\end{array}$ \\
\hline $\begin{array}{l}\text { - plots with Dactylis } \\
\text { omerata and Trifolium } \\
\text { pens }\end{array}$ & 12 & $14 \pm 2.35$ & $\begin{array}{c}6.94 \\
(6.69-7.42)\end{array}$ & $\begin{array}{c}5.31 \\
(4.88-7.42)\end{array}$ & $\begin{array}{c}6.41 \\
(5.80-7.00)\end{array}$ & $\begin{array}{c}6.19 \\
(5.41-7.07)\end{array}$ \\
\hline $\begin{array}{l}\text { I - plots with Holcus } \\
\text { natus }\end{array}$ & 7 & $14 \pm 1.60$ & $\begin{array}{c}7.00 \\
(6.77-7.21) \\
\end{array}$ & $\begin{array}{c}5.32 \\
(5.24-5.41)\end{array}$ & $\begin{array}{c}6.41 \\
(5.81-7.06) \\
\end{array}$ & $\begin{array}{c}5.93 \\
(5.15-6.50)\end{array}$ \\
\hline $\begin{array}{l}\text { V - plots with Arrhen- } \\
\text { atherum elatius }\end{array}$ & 16 & $15 \pm 2.69$ & $\begin{array}{c}7.05 \\
(6.70-7.40)\end{array}$ & $\begin{array}{c}5.31 \\
(4.91-5.68)\end{array}$ & $\begin{array}{c}6.57 \\
(5.50-7.40)\end{array}$ & $\begin{array}{c}6.32 \\
(5.94-6.87)\end{array}$ \\
\hline
\end{tabular}


Tab. 6. Comparison of Utility Value of Meadows (UVM) on the study area based on the Use Value Index (UVI) numbers according to Filipek (1973)

\begin{tabular}{|c|c|c|c|c|c|c|c|}
\hline \multirow[b]{2}{*}{ Plots group name } & \multirow[b]{2}{*}{$\begin{array}{l}\text { No. plot } \\
\text { in the } \\
\text { area }\end{array}$} & \multicolumn{6}{|c|}{ Feeding value of plants } \\
\hline & & $\begin{array}{l}\text { Very good } \\
10-9\end{array}$ & $\begin{array}{c}\text { Good } \\
8-7\end{array}$ & $\begin{array}{l}\text { Medium } \\
6-4\end{array}$ & $\begin{array}{c}\text { Small } \\
3-1\end{array}$ & $\begin{array}{c}\text { None } \\
0\end{array}$ & $\begin{array}{c}\text { Poisonous } \\
\text { plants } \\
(-1)-(-3) \\
\end{array}$ \\
\hline \multirow{16}{*}{$\begin{array}{l}\text { Group I - plots with } \\
\text { Phleum pratense and } \\
\text { Vicia cracca }\end{array}$} & 34 & - & - & 6.72 & - & - & - \\
\hline & 27 & - & 7.66 & - & - & - & - \\
\hline & 33 & - & - & 6.63 & - & - & - \\
\hline & 49 & - & 8.53 & - & - & - & - \\
\hline & 43 & - & - & 5.97 & - & - & - \\
\hline & 46 & - & 8.19 & - & - & - & - \\
\hline & 32 & - & - & 6.89 & - & - & - \\
\hline & 41 & - & 7.96 & - & - & - & - \\
\hline & 18 & - & 7.56 & - & - & - & - \\
\hline & 13 & - & 7.91 & - & - & - & - \\
\hline & 4 & - & 7.88 & - & - & - & - \\
\hline & 19 & - & - & 6.21 & - & - & - \\
\hline & 42 & - & - & 4.03 & - & - & - \\
\hline & 14 & - & - & - & 3.25 & - & - \\
\hline & 35 & - & 7.42 & - & - & - & - \\
\hline & 8 & - & - & 5.72 & - & - & - \\
\hline $\begin{array}{l}\text { Average UVM for all } \\
\text { group } \mathrm{I} \pm \mathrm{SD}\end{array}$ & \multicolumn{7}{|c|}{ Medium - $6.78 \pm 1.48$} \\
\hline \multirow{12}{*}{$\begin{array}{l}\text { Group II - plots with } \\
\text { Dactylis glomerata and } \\
\text { Trifolium repens }\end{array}$} & 40 & - & 8.13 & - & - & - & - \\
\hline & 7 & - & 7.26 & - & - & - & - \\
\hline & 48 & - & - & 6.69 & - & - & - \\
\hline & 37 & - & 7.93 & - & - & - & - \\
\hline & 26 & - & 7.68 & - & - & - & - \\
\hline & 5 & - & 7.12 & - & - & - & - \\
\hline & 22 & - & - & 5.17 & - & - & - \\
\hline & 29 & - & - & 6.62 & - & - & - \\
\hline & 28 & - & 7.52 & - & - & - & - \\
\hline & 23 & - & - & 6.02 & - & - & - \\
\hline & 21 & - & - & 5.97 & - & - & - \\
\hline & 36 & - & 7.06 & - & - & - & - \\
\hline $\begin{array}{l}\text { Average UVM for all } \\
\text { group II } \pm S D\end{array}$ & \multicolumn{7}{|c|}{ Medium $-6.93 \pm 0.76$} \\
\hline \multirow{7}{*}{$\begin{array}{l}\text { Group III - plots with } \\
\text { Holcus lanatus }\end{array}$} & 31 & - & - & 6.13 & - & - & - \\
\hline & 30 & - & - & 6.12 & - & - & - \\
\hline & 11 & - & - & 6.67 & - & - & - \\
\hline & 6 & - & 7.10 & - & - & - & - \\
\hline & 25 & - & - & 6.78 & - & - & - \\
\hline & 50 & - & - & 6.84 & - & - & - \\
\hline & 24 & - & - & 5.38 & - & - & - \\
\hline
\end{tabular}




\begin{tabular}{|c|c|c|c|c|c|c|c|}
\hline \multirow{2}{*}{$\begin{array}{l}\text { Average UVM for all } \\
\text { group III } \pm \text { SD } \\
\text { Group IV - plots with }\end{array}$} & \multicolumn{7}{|c|}{ Medium - $6.43 \pm 0.53$} \\
\hline & 10 & - & 7.86 & - & - & - & - \\
\hline Arrhenatherum elatius & 9 & - & 8.07 & - & - & - & - \\
\hline & 16 & - & 7.08 & - & - & - & - \\
\hline & 1 & - & 7.62 & - & - & - & - \\
\hline & 2 & - & 7.25 & - & - & - & - \\
\hline & 3 & - & 7.82 & - & - & - & - \\
\hline & 15 & - & 8.19 & - & - & - & - \\
\hline & 39 & - & 8.04 & - & - & - & - \\
\hline & 12 & - & 7.65 & - & - & - & - \\
\hline & 51 & - & 8.78 & - & - & - & - \\
\hline & 17 & - & 7.06 & - & - & - & - \\
\hline & 45 & - & 7.65 & - & - & - & - \\
\hline & 44 & 9.25 & - & - & - & - & - \\
\hline & 47 & - & - & 6.64 & - & - & - \\
\hline & 20 & - & 8.65 & - & - & - & - \\
\hline & 38 & - & - & 5.75 & - & - & - \\
\hline $\begin{array}{l}\text { Average UVM for all } \\
\text { group IV } \pm S D\end{array}$ & \multicolumn{7}{|c|}{ Good $-7.71 \pm 1.49$} \\
\hline
\end{tabular}




\begin{abstract}
The quality of the botanical composition of meadows and pastures is decisive in the profitability of livestock farming. The aim of this study was to examine the floristic composition of meadows and pastures of the Wadowice commune and to assess their feed value. Field explorations were carried out in June 2016 throughout the commune. Floristic lists were made on 51 designated plots using the estimated Klapp method. Four groups of similar plots with the following dominant species were distinguished in the analysed area: I - plots with Phleum pratense and Vicia cracca, II - plots with Dactylis glomerata and Trifolium repens, III - plots with Holcus lanatus, and IV - plots with Arrhenatherum elatius. The results of the research showed that, in the area of this commune, meadows and pastures were characterised by average and good pasture values, which favours their use for agricultural purposes. Improving the quality of the botanical composition of plots of medium fodder value could be achieved through proper care and sustainable use.
\end{abstract}

Key words: Ellenberg's indicators, grasslands, habitat, Klapp method, Utility Value of Meadows (UVM)

Received: [2020.03.20]

Accepted: [2020.05.15]

\title{
Ocena składu florystycznego runi użytków zielonych gminy Wadowice
}

Streszczenie

Jakość składu botanicznego łąk i pastwisk ma kluczowe znaczenie w opłacalności hodowli zwierząt gospodarskich. Celem niniejszej pracy było zbadanie składu florystycznego łąk i pastwisk gminy Wadowice oraz ocena ich wartości paszowej. Eksploracje terenowe zostały przeprowadzone w czerwcu 2016 roku na obszarze całej gminy. Na 51 wyznaczonych poletkach dokonano spisów florystycznych, przy użyciu szacunkowej metody Klappa. Na analizowanym terenie stwierdzono obecność czterech grup poletek podobnych z następującymi gatunkami dominującymi: I - z Phleum pratense i Vicia cracca, II - z Dactylis glomerata i Trifolium pratense, III - z Holcus lanatus, IV - z Arrhenatherum elatius. Rezultaty przeprowadzonych badań pokazały, że na obszarze tej gminy łąki i pastwiska odznaczają się średnią oraz dobrą wartością pastewną, co sprzyja ich wykorzystaniu do celów rolniczych. Poprawę jakości składu botanicznego płatów o średniej wartości pastewnej można uzyskać poprzez odpowiednią pielęgnację oraz zrównoważone użytkowanie.

Słowa kluczowe: wskaźniki Ellenberga, użytki zielone, siedlisko, metoda Klappa, wartość użytkowa łąk (WUE)

\section{Information on the author}

\section{Ksenia Strzeżoń}

She was a student at the Department of Botany of the Pedagogical University. She is interested in herbalism and flora as well as the dynamics of plants communities in non-forest areas. 